\title{
Persepsi Masyarakat Terhadap Pengelolaan Lingkungan Di Kelurahan Amban Kabupaten Manokwari
}

\author{
Agustina M Tanati'; Rima H Siburian'; Agustinus Murdjoko \\ ${ }^{1}$ Universitas Papua, Manokwari 98314 \\ ${ }^{2}$ r.siburian@unipa.ac.id
}

\begin{abstract}
Abstrak
Pengelolaan lingkungan pada kelurahan Amban merupakan suatu hal yang menarik karena kawasan ini merupakan salah satu kawasan padat penduduk di Kabupaten Manokwari. Tujuan penelitian ini adalah untuk mengetahui bagaimana persepsi masyarakat terhadap pengelolan lingkungan pada kawasan ini. Metode yang digunakan dalam penelitian ini adalah metode survey dan observasi dengan teknik wawancara yang dibagi dengan pembagian kasus atas enam kategori penilaian, dan didukung oleh data sekunder. Hasil penelitian menunjukkan bahwa sebagian besar masyarakat yang berada pada kelurahan Amban sangat setuju terhadap pola perencanaan pemanfaatan, pengendalian, pemeliharaan, pengawasan serta penegakan hukum yang dilakukan pada wilayah ini. Data ini diperoleh dari tiga wilayah yang tersebar pada wilayah Kelurahan Amban Manokwari.
\end{abstract}

Kata kunci: Persepsi masyarakat, Pengelolaan lingkungan, Kelurahan Amban

\section{PENDAHULUAN}

Pertumbuhan dan perkembangan penduduk dalam suatu kawasan, dapat berdampak positif maupun negatif terutama bagi lingkungan itu sendiri. Masyarakat merupakan bagian dari suatu kawasan yang hidup saling berinteraksi, bekerja sama serta hidup dalam suatu wilayah tertentu, baik itu di sebuah kampung atau desa, kelurahan, distrik, kota, provinsi bahkan negara dan memiliki kebudayaan masing-masing. Di dalam hidup bermasyarakat, interaksi antara anggota masyarakat akan membentuk suatu sistem lingkungan yang beragam. Lingkungan tempat hidup seseorang sangat berpengaruh pada kehidupannya dan juga mempengaruhi lingkungan tempat anggota masyarakat tersebut berasosiasi.

Pengelolaan lingkungan merupakan upaya terpadu dalam memanfaatkan, menata, memelihara, mengawas, mengendalikan, memulihkan, dan mengembangkan lingkungan serta ekosistem tempat hidup. Hal ini bertujuan agar manusia yang hidup dalam lingkungan tersebut dapat memanfaatkan sumberdaya tersebut dengan bijaksana dan berkesinambungan bagi kepentingan manusia dan lingkunganya Kementrian Lingkungan Hidup (2013).

Kelurahan Amban merupakan salah satu kelurahan di Kabupaten Manokwari Papua Barat yang merupakan daerah lingkungan Kampus Universitas Papua. Kondisi masyarakat yang bermukim pada wilayah ini cukup beragam, baik dari kalangan akademisi maupun masyarakat umum. Pertumbuhan populasi pada daerah ini cukup 
pesat, sejalan dengan pengembangan kampus dan pembukaan beberapa wilayah sekitar Kelurahan Amban, terkait dengan kota Manokwari sebagai ibu kota Propinsi Papua Barat. Masalah lingkungan perkotaan yang terjadi di Kelurahan Amban disebabkan oleh dua faktor, yakni faktor alam dan faktor manusia itu sendiri. Salah satu faktor yang disebabkan oleh manusia adalah pengelolaan lingkungan hidup yang dapat berdampak pada kondisi dan kualitas lingkungan.

Peningkatan jumlah penduduk dapat berdampak pada persepsi tiap masyarakat yang berbeda dalam melihat lingkungan tempat tinggal mereka. Cara pandang dapat diartikan juga sebagai persepsi, dimana cara pandang seseorang dalam memandang atau mengartikan sesuatu. Persepsi dari tiap masyarakat terhadap sesama dan lingkungan di sekitar mereka pun sangatlah berbeda-beda, bisa saja secara positif maupun secara negatif. Cara pandang ini sangat bergantung atau kembali dari siapa yang akan memberikan persepsi tersebut.

Peningkatan penggunaan lahan di Kelurahan Amban mengakibatkan terjadinya tekanan penduduk terhadap lahan dimana luas lahan yang tersedia tidak mengalami penambahan sedangkan penduduk terus bertambah. Selain itu, masyarakat yang mendiami kelurahan Amban khususnya di perumahan dosen dan pegawai memiliki pemahaman tentang pengelolaan lingkungan hidup yang mungkin saja dapat berbeda. Hal ini diduga dapat disebabkan karena faktor pendidikan maupun pengalaman seseorang dalam berinteraksi dengan lingkungannya. Disamping pendidikan, pekerjaan, usia, gender bahkan kondisi sosial ekonomi, dapat juga mempengaruhi cara pandang sesorang terhadap lingkungan.

Berdasarkan latar belakang tersebut maka informasi mengenai persepsi masyarakat terhadap pengelolaan lingkungan Kelurahan Amban yang terdiri dari berbagai lapisan masyarakat yang sangat beragam menjadi sangat perlu sebagai bahan pertimbangan dalam pengelolaan lingkungan Amban yang merupakan bagian dari Kabupaten Manokwari ibu kota Propinsi Papua Barat.

\section{METODE PENELITIAN}

Penelitian ini berlangsung dari bulan Mei-Juni 2020, pada Kelurahan Amban Distrik Manokwari Barat Kabupaten Manokwari Propinsi Papua Barat, seperti pada Gambar 1.

Metode yang digunakan dalam penelitian ini adalah metode survey dan observasi dengan teknik wawancara. Variabel penelitian meliputi persepsi masyarakat terhadap pengelolaan lingkungan hidup yang meliputi beberapa indicator diantaranya:

1. Persepsi masyarakat terhadap perencanaan

2. Persepsi masyarakat terhadap pemanfaatan

3. Persepsi masyarakat terhadap pengendalian

4. Persepsi masyarakat terhadap pemeliharaan

5. Persepsi masyarakat terhadap pengawasan

6. Persepsi masyarakat terhadap penegakan hukum 


\section{Median Volume 12 Nomor 3 Bulan Oktober 2020}

Doi http://doi.org/md.v12i3.761

Data indikator tersebut kemudian diskoring berdasarkan penilaian masyarakat sehingga diperoleh data persepsi masyarakat yang merupakan skor nilai rataan penilaian. Data tersebut dikumpulkan dengan menggunakan teknik wawancara dengan kuisioner yang telah disiapkan, dokumentasi serta observasi partisipatif. Pemilihan responden dilakukan dengan purposive sampling, berdasarkan pertimbangan dan tujuan penelitian. Metode pengambilan jumlah sampel pada penelitian ini menggunakan rumus Slovin (Kusmayadi dan Sugiarto, 2000), dengan taraf signifikansi $15 \%$, seperti :

$$
\mathrm{n}=\frac{\mathrm{N}}{1+\mathrm{N}(\mathrm{e}) 2}
$$

Dimana; $\mathrm{n}=$ ukuran sample

$\mathrm{N}=$ Ukuran populasi

$\mathrm{e}=\operatorname{taraf}$ kepercayaan $15 \%$

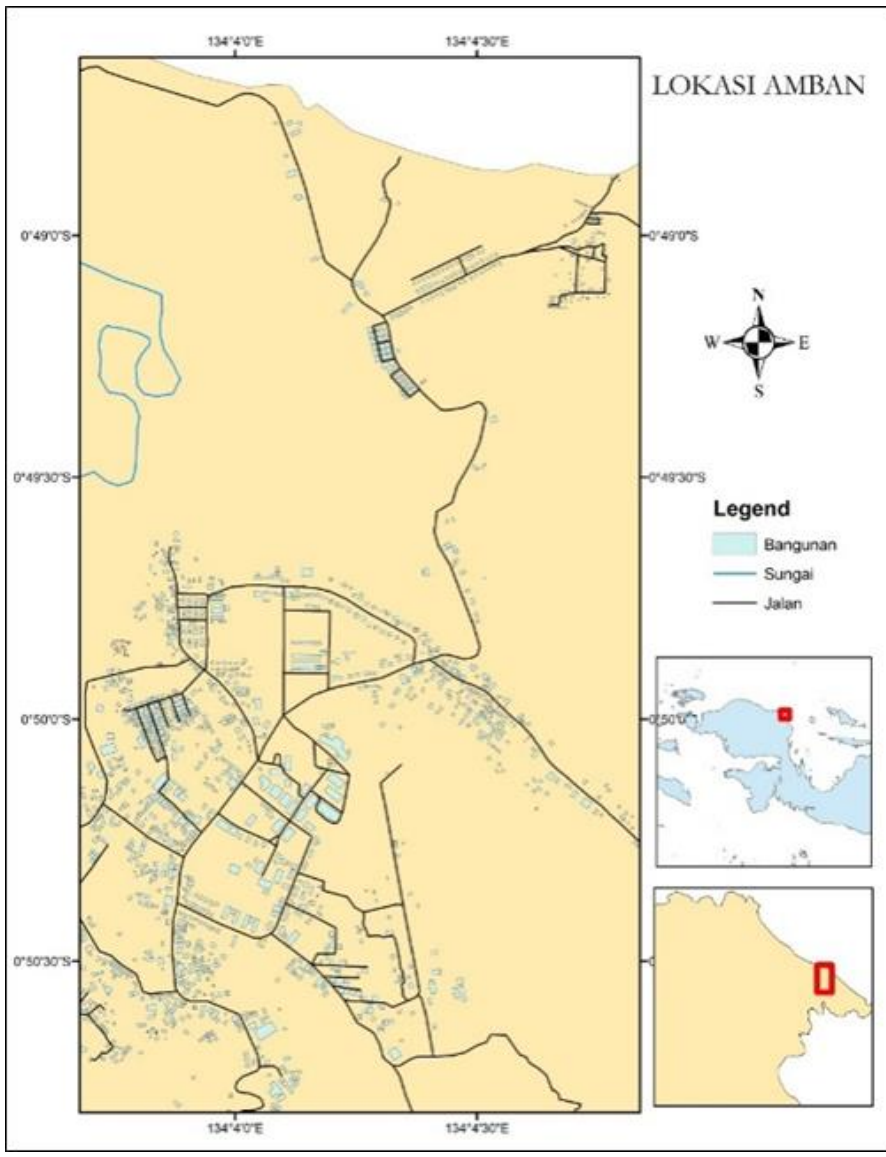

Gambar 1. Peta kelurahan Amban, Distrik Manokwari Barat

\section{HASIL DAN PEMBAHASAN}

Pengelolaan lingkungan merupakan upaya terpadu untuk melestarikan fungsi lingkungan hidup yang meliputi kebijaksanaan penataan, pemanfaatan, pengembangan, 


\section{Median Volume 12 Nomor 3 Bulan Oktober 2020}

Doi http://doi.org/md.v12i3.761

pemeliharaan, pemulihan, pengawasan dan pengendalian lingkungan hidup. Bila dilihat dari luas wilayah untuk masing-masing kelurahan yang berada di Kabupaten Manokwari, maka Kelurahan Amban merupakan kelurahan yang memiliki wilayah yang lebih luas dari kelurahan lain di Kabupaten Manokwari, seperti pada Gambar 2.

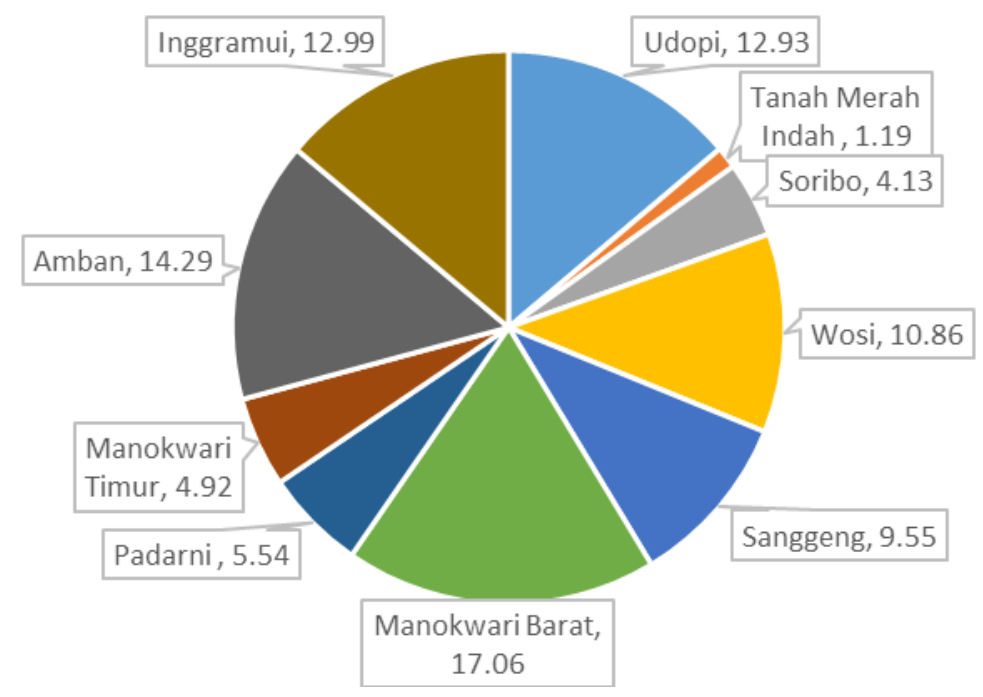

Gambar 2. Persentase Luas Wilayah di Kabupaten Manokwari (BPS Manokwari, 2019)

Berdasarkan data yang diperoleh dari Kelurahan Amban, maka jumlah penduduk yang berdomisili pada kelurahan ini adalah 10.944 jiwa. Dengan demikian maka minimal jumlah responden yang akan akan diambil dalam penelitian ini adalah sebanyak 44 orang. Berdasarkan karakteristik umur maka yang dijadikan responden dalam penelitian ini dikelompokkan atas 4 bagian seperti pada Tabel 1 .

Tabel 1 Karakteristik responden berdasarkan jenis kelamin

\begin{tabular}{cccc}
\hline No & Umur (Tahun) & Frekuensi (Jiwa) & Persentase \\
\hline 1 & $21-34$ & 9 & 20.45 \\
2 & $35-48$ & 20 & 45.45 \\
3 & $49-62$ & 14 & 31.82 \\
4 & $63-77$ & 1 & 2,28 \\
\hline & Jumlah & 44 & 100,00 \\
\hline
\end{tabular}

Putirulan et al 2019 menyatakan bahwa umur bukanlah faktor satu-satunya dalam menentukan apa yang dikerjakannya dan bagaimana hasil pekerjaan seseorang. Umur hanya dapat menentukan seberapa lama dan seberapa kuat seseorang dapat melakukan pekerjaannya.

Karakteristik responden yang juga mendapatkan perhatian dalam penelitian ini adalah pendidikan. Persentase responden dengan tingkat pendidikan terakhir berasal dari perguruan tinggi sebanyak $54 \%$, Sekolah Menengah Atas (30 \%), Sekolah Menengah Tingkat pertama (14\%) dan Sekolah Dasar (2\%). Bila dilihat dari tingkat 


\section{Median Volume 12 Nomor 3 Bulan Oktober 2020}

Doi http://doi.org/md.v12i3.761

pendidikan maka hal ini mempengaruhi cara pandang dan berpikir seseorang tentang lingkungan. Jenis pekerjaan merupakan salah satu karakteristik yang juga dinilai dalam penelitian ini. Aktifitas yang direncanakan maupun dilakukan akan sangat berdampak terhadap pengelolaan sumberdaya yang dikelola baik pada lingkungan tempat tinggal maupun saat beraktifitas diluar lingkungan tempat tinggal. $64 \%$ responden dalam penelitian ini adalah pegawai negeri, Karyawan swasta $(21 \%)$, Wirausaha (12\%) dan TNI/POLRI (3\%).

\section{Persepsi Masyarakat dalam pengelolaan lingkungan}

Persepsi masyarakat terhadap pengelolaan lingkungan hidup di Kecamatan Manokwari barat Kelurahan Amban Kota Manokwari merupakan penilaian masyarakat terhadap upaya sistematis dan terpadu yang dilakukan untuk melestarikan fungsi lingkungan hidup dan mencegah terjadinya pencemaran dan/atau kerusakan lingkungan hidup yang dilaksanakan oleh pemerintah daerah dan masyarakat. Indikator pengelolaan lingkungan hidup meliputi perencanaan, pemanfaatan, pengendalian, pemeliharaan, pengawasan, dan penegakan hukum.

\section{a. Persepsi Masyarakat terhadap Perencanaan}

Persepsi masyarakat terhadap perencanaan merupakan penilaian masyarakat terhadap upaya internalisasi aspek lingkungan hidup ke dalam perencanaan dan penyelenggaraan pembangunan di Kelurahan Amban meliputi inventarisasi lingkungan hidup, penetapan wilayah ekoregion, dan pembangunan berkelanjutan, seperti pada Tabel 2.

Tabel 2. Persepsi Masyarakat Terhadap Perencanaan

\begin{tabular}{|c|c|c|c|c|}
\hline \multirow{3}{*}{ Kriteria } & \multicolumn{4}{|c|}{ Persepsi } \\
\hline & $\begin{array}{l}\text { Sangat } \\
\text { setuju }\end{array}$ & Setuju & Tidak setuju & $\begin{array}{l}\text { Sangat tidak } \\
\text { setuju }\end{array}$ \\
\hline & $\%$ & $\%$ & $\%$ & $\%$ \\
\hline \multicolumn{5}{|l|}{ Inventarisasi lingkungan } \\
\hline $\begin{array}{l}\text { a. Data dan Informasi } \\
\text { pengelolaan }\end{array}$ & 9.09 & 65,91 & 22,73 & 2,27 \\
\hline $\begin{array}{l}\text { b. Data dan Informasi } \\
\text { pengelolaan }\end{array}$ & 59,09 & 31,82 & 6,82 & 2,27 \\
\hline \multicolumn{5}{|l|}{ Penetapan wilayah ekoregion } \\
\hline a. Karakteristik Wilayah & 11,36 & 43,18 & 31,82 & 13,64 \\
\hline $\begin{array}{l}\text { b. Kemampuan mendukung } \\
\text { Kehidupan }\end{array}$ & 11,36 & 54,55 & 20,45 & 13,64 \\
\hline $\begin{array}{l}\text { c. Kemampuan mengatasi } \\
\text { masalah lingkungan }\end{array}$ & 2,27 & 79,55 & 15,91 & 2,27 \\
\hline Pembangunan Berkelanjutan & 2,27 & 65,91 & 27,27 & 4,55 \\
\hline
\end{tabular}

\section{b. Persepsi Masyarakat terhadap Pemanfaatan}

Persepsi masyarakat terhadap permanfaatan merupakan penilaian masyarakat terhadap pemanfaatan sumber daya alam yang dilaksanakan berdasarkan daya dukung 


\section{Median Volume 12 Nomor 3 Bulan Oktober 2020}

Doi http://doi.org/md.v12i3.761

dan daya tampung lingkungan di kelurahan Amban meliputi keberlanjutan fungsi, keberlanjutan produktivitas, dan kesejahteraan masyarakat, seperti dalam Tabel 3.

Tabel 3. Persepsi Masyarakat Terhadap Pemanfaatan

\begin{tabular}{lcccc}
\hline \multirow{2}{*}{ Kriteria } & \multicolumn{4}{c}{ Persepsi } \\
\cline { 2 - 5 } & $\begin{array}{c}\text { Sangat } \\
\text { setuju }\end{array}$ & Setuju & Tidak setuju & $\begin{array}{c}\text { Sangat tidak } \\
\text { setuju }\end{array}$ \\
\cline { 2 - 5 } & $\%$ & $\%$ & $\%$ & $\%$ \\
\hline Keberlanjutan fungsi & 2,27 & 63,64 & 29,55 & 4,55 \\
Keberlanjutan produktifitas & 4,55 & 56,82 & 34,09 & 4,55 \\
Kesejahteraan masyarakat & 6,82 & 68,18 & 22,73 & 2,27 \\
\hline
\end{tabular}

\section{c. Persepsi masyarakat terhadap pengendalian lingkungan}

Persepsi masyarakat terhadap pengendalian merupakan penilaian masyarakat terhadap pengendalian pencemaran dan kerusakan lingkungan hidup di Kecamatan Manokwari Barat Kelurahan Amban meliputi pencegahan, penanggulangan, dan pemulihan seperti dalam Tabel 4.

Tabel 4. Persepsi Masyarakat Terhadap Pengendalian Lingkungan

\begin{tabular}{ccccc}
\hline \multirow{2}{*}{ Kriteria } & \multicolumn{4}{c}{ Persepsi } \\
\cline { 2 - 5 } & $\begin{array}{c}\text { Sangat } \\
\text { setuju }\end{array}$ & Setuju & $\begin{array}{c}\text { Tidak } \\
\text { setuju }\end{array}$ & $\begin{array}{c}\text { Sangat tidak } \\
\text { setuju }\end{array}$ \\
\cline { 2 - 5 } & $\%$ & $\%$ & $\%$ & $\%$ \\
\hline Pencegahan & 2,27 & 72,73 & 18,18 & 6,82 \\
\hline a. Upaya pencegahan & 9,09 & 72,27 & 11,36 & 2,27 \\
b. Sosialisasi lingkungan & 2,27 & 70,45 & 25 & 2,27 \\
c. Peran pencegahan & & & & \\
\hline Penanggulangan & 4,55 & 77,27 & 15,91 & 2,27 \\
\hline a. Upaya penanggulangan & 6,82 & 68,18 & 22,73 & 2,27 \\
b. Peran penanggulangan & & & & \\
\hline Pemulihan & 6,82 & 75 & 15,91 & 2,27 \\
\hline a. Upaya penghentian & 2,27 & 75 & 20,45 & 2,27 \\
b. Peran penghentian &
\end{tabular}

\section{Pengelolaan Serta Pencegahan oleh Masyarakat}

Hasil penelitian ini menunjukkan bahwa masyarakat di Amban sudah paham akan pengelolaan lingkungan yang diterapkan oleh program swadaya dan program pemerintah dalam hal ini Dinas Lingkungan Hidup Kabupaten Manokwari. Dari komposisi jenis kelamin, ternyata kedua gender ini sudah menerapkan pengelolaan akan perencanaan dan pengelolaan lingkungan. Berkaitan dengan itu, menurut Setiawan dan Fithrah (2018), bahwa jenis kelamin tidak berpengaruh terhadap pemahaman dalam bentuk persepsi dan sikap masyarakat akan pengelolaan lingkungan hidup. Hal ini di sebabkan oleh kemajemukan suku, pendidikan yang relative tinggi, aksesibilitas dengan fasilitas publik yang baik. Di samping itu, transparansi dari program swadaya yang 


\section{Median Volume 12 Nomor 3 Bulan Oktober 2020}

dikelola oleh masyarakat biasa terlaksana dengan baik dari tingkat Kabupaten sampai tingkat bawah di RT atau pun RW. Variasi umur di Kelurahan Amban didominasi oleh kelas usia produktif (35-62 tahun) pada Tabel 1, memperlihatkan bahwa kebanyakan dari masyarakat di Kelurahan Amban adalah orang yang sudah bekerja dan memiliki profesi tetap seperti Aparatur Sipil Negara (ASN), swasta, dan mata pencaharian tani. Oleh karena itu, masyakat ini lebih paham akan arti penting pengelolaan lingkungan dengan informasi yang bias diperoleh dari instansi terkait seperti Dinas Lingkungan Hidup, Puskesmas, dan sekolah-sekolah.

Sejauh pengamatan selama penelitian ini, pengelolaan swadaya ini berupa penataan drainase, walaupun beberapa tempat belum optimal dikarenakan faktor pendanaan dan bentuk topografi yang bergunung dan bergelombang sering menjadi faktor penghambat (Arief et al 2019). Faktor pendanaan ini merupakan faktor pembatas yang umum dalam pengelolaan lingkungan secara swadaya (Fitryarini, 2014). Hal yang berbeda, program pengelolaan lingkungan yang berbasis pada instansi pemerintah seperti tempat pembuangan sampah sementara di beberapa tempat seperti di depan Kampus UNIPA, jalan menuju Amban Pantai, Perumahan Amban Permai dan beberapa titik lainnya mendapat perhatian yang baik dari masyarakat Amban secara umum. Hal ini dapat dilihat dari persepsi masyarakat yang baik untuk penanganan sampah ini terutama dalam mengolah sampah organik menjadi pupuk (Atkana et al 2019). Sosialisasi dan keterbukaan antara masyarakat dan pemerintah menjadi hal yang krusial dalam pelaksanaan program ini (Isthofiyani et al, 2016). Hal ini terbukti dengan keterlibatan masyarakat dalam bentuk organisasi kepemudaan, kampus, pihak gereja dan masjid yang dapat dilihat dari keaktifan mereka untuk mengumpulkan sampah dari setiap wilayah kerja sampai ke tempat pengumpulan sampah sementara. Faktor lain yang mendukung adalah adanya insentif dari Dinas Lingkungan Hidup Kabupaten Manokwari kepada pengelola dari tingkat bawah di tatanan masyarakat.

Masyarakat Kelurahan Amban juga sudah memahami secara betul fungsi keberadaan sumber daya alam yang akan mendukung fungsi-fungsi dalam pengelolaan lingkungan seperti Taman Wisata Alam Gunung Meja. Persepsi masyarakat secara umum adalah mendukung keberadaan sumber daya alam tersebut dalam rangka menunjang keberadaan sumber air bagi masyarakat. Hal tersebut sudah berlangsung sekian generasi yang merasakan arti penting keberadaan sumber daya alam seperti Gunung Meja. Sejauh ini, masyarakat sudah sangat kritis dengan beberapa kerusakan atau alih fungsi dari keberadaan sumber daya alam seperti beberapa titik sungai yang dipenuhi sampah yang berasal dari hulu (Sungai Pami dan Nuni). Hal tersebut, sangat disesalkan oleh masyarakat Amban, sehingga mereka mengusulkan kepada Dinas Lingkungan Hidup Kabupaten Manokwari agar menjadi perhatian dalam pemberian sanksi kepada mereka yang tidak mengindahkan kebersihan sungai tersebut. Hal ini dapat dilihat dari persepsi masyarakat Amban yang setuju akan penerapan sanksi dalam melanggar bagi mereka yang membuang sampah tidak pada tempatnya. Namun, proses penyusunan peraturan tersebut belum secara nyata dilaksanakan karena mekanisme 


\section{Median Volume 12 Nomor 3 Bulan Oktober 2020}

Doi http://doi.org/md.v12i3.761

birokrasi pemerintah daerah yang harus dilalui sampai peraturan tersebut bisa dibuat dan diterapkan. Penerapan mekanisme ini merupakan prosedur terencana yang dikelola oleh organisasi perangkat daerah (OPD) terkait (Irawan et al, 2017).

Hasil penelitian ini dapat menjadi pertimbangan informasi kepada pemerintah daerah akan persepsi masyarakat Amban yang secara umum sudah memahami akan pengelolaan lingkungan dari perencanaan, pelaksanaan, dan evaluasi secara keseluruhan. Pengelolaan lingkungan ini perlu mendapatkan dukungan penuh dari pemerintah kabupaten dalam bentuk program-program yang melibatkan masysarakat secara langsung maupun tidak langsung.

\section{DAFTAR PUSTAKA}

Arief S, Siburian R H, Wahyudi. 2019. Tingkat Kerentanan Banjir Kota Sorong Papua Barat. Median Volume 11 Nomor 2 Bulan Juni 2019. pp 23-27.

Atkana Y, Siburian R H, Noya A. 2019. Analisis Kompos Sampah Organik Dan Aplikasinya Terhadap Anakan Gaharu. EnviroScienteae Vol. 15 No. 2, Agustus 2019, pp 263-270.

Irawan, A., Iwanuddin, I. and Ekawati, S., 2017. Analisis Persepsi dan Perilaku Masyarakat Terhadap Keberadaan Kawasan KPHP Model Poigar. Jurnal Penelitian Sosial dan Ekonomi Kehutanan, 14(1), pp.71-82.

Isthofiyani, S.E., Prasetyo, A.P.B. and Iswari, R.S., 2016. Persepsi Dan Pola Perilaku Masyarakat Bantaran Sungai Damar Dalam Membuang Sampah Di Sungai. Journal of Innovative Science Education, 5(2), pp.128-136.

Kementerian Lingkungan Hidup. (2013). Rumusan Hasil Rapat Koordinasi Nasional Perlindungan dan Pengelolaan Lingkungan Hidup 2013. Diakses dari http://www.menlh.go.id/rumusan-hasil-rapat-koordinasi-nasional-perlindungandan-pengelolaan-lingkungan-hidup-2013/ [20 September 2020]

Kusmayadi dan Endar Sugiarto. (2000). Metodologi Penelitian dalam Bidang Kepariwisataan. Jakarta: PT Gramedia Pustaka Utama. LP3ES.

Putirulan Y, Siburian R H, Tjolli I. 2019. The level of community participation on forest and land rehabilitation program in Sorong City. Ecology Environment \& Conservation journal. 25 (2) : 2019; pp. (103-109).

Setiawan, B. and Fithrah, D.S., 2018. Kampanye Gerakan Indonesia Diet Kantong Plastik Dalam Membentuk Persepsi Masyarakat Bandung. Jurnal Manajemen Komunikasi, 2(2), pp.102-117. 